\title{
A minimális residualis betegség vizsgálatának jelentősége myeloma multiplex kezelése után
}

\author{
Szendrei Tamás dr. ${ }^{1}$ - Plander Márk dr. ${ }^{1}$ \\ Szabó Zsuzsanna dr. ${ }^{1}$ - Kereskai László dr. ${ }^{2}$ - Kajtár Béla dr. ${ }^{2}$ \\ Papp Gergely dr. ${ }^{3}$ - Iványi János László dr. ${ }^{1}$ \\ ${ }^{1}$ Markusovszky Egyetemi Oktatókórház, Hematológia Osztály, Szombathely \\ ${ }^{2}$ Pécsi Tudományegyetem, Általános Orvostudományi Kar, Pathologiai Intézet, Pécs \\ ${ }^{3}$ Semmelweis Egyetem, Általános Orvostudományi Kar, I. Patológiai Intézet, Budapest
}

\begin{abstract}
Bevezetés: Számos klinikai vizsgálat igazolta myeloma multiplexben a minimális residualis betegség (MRD) prognosztikai jelentőségét.

Célkitüzés: A 2007 és 2017 között kezelt myelomás beteganyagunk feldolgozása, első vonalban adott kezelés után, áramlásos citometriával (FCM) meghatározott MRD függvényében.

Módszer: A fenti időszakban kezelt 107 betegből 56 esetben (medián életkor: 68 év) történt MRD-felmérés a kezelés után. A kezelések 91\%-ában bortezomibbázisú indukció, 50\%-ában autológcsontvelő-transzplantáció (ASCT) is történt. MRD-meghatározás: csontvelői mintából történt FCM (az esetek többségében kórházunkban, BD FACScan, 3 szín, panel: CD38, CD138, CD19, CD45, CD56, CD28, CD117, cyKappa, cyLambda, 100000 esemény). Statisztikai analízis: SPSS 13.0.

Eredmények: Az MRD-negatív ( $\mathrm{n}=22$ ) betegek progressziómentes (PFS) és teljes túlélése (OS) is szignifikánsan hosszabb az MRD-pozitív ( $\mathrm{n}=34$ ) betegekénél (PFS medián 54 vs. 22 hónap, $\mathrm{p}=0,001,5$ éves túlélés 79 vs. 21\%, $\mathrm{p}=0,002)$. A komplett remisszióba (CR) került betegcsoporton $(\mathrm{n}=29)$ belül is szignifikánsan szétváltak a túlélési görbék (MRD-negatív CR [ $\mathrm{n}=17$ ] PFS: 60 hónap, MRD-pozitív CR [n = 12]: 21 hónap, p<0,001). MRD-negatív „nagyon jó parciális remisszióban” (VGPR) $(\mathrm{n}=5)$ hasonló PFS-t mértünk (54 hónap), mint MRD-negatív CR esetén. ASCT-n átesett, MRD-negatív betegeknél $(\mathrm{n}=11)$ találtuk a leghosszabb PFS-t (68 hónap, p<0,001), míg a transzplantáció után MRD-pozitív betegeknél $(\mathrm{n}=18)$ hasonlóan rövid (25 hónapos) volt a PFS, mint akiknél $(\mathrm{n}=$ 15 ) nem történt transzplantáció, és volt kimutatható residualis betegségük (21 hónap). Multivarianciaanalízis (stádium, citogenetikai rizikó, ASCT) alapján is független prognosztikai faktor az MRD a PFS és OS szempontjából, nem találtunk azonban összefüggést az MRD és az alábbi paraméterek között: stádium, citogenetikai rizikó, kezelési ciklusok száma, ASCT.

Következtetés: A myeloma indukciós kezelését követóen elért válasz mélysége a túlélés független prediktora. Indokolt a laborvizsgálatok mellett meghatározni a maradék betegség tömegét, és megfontolni a konszolidáló és/vagy fenntartó kezelést MRD-pozitív esetekben ASCT után, MRD eradikálására kell törekedni a kezelésre alkalmas betegeknél. Orv Hetil. 2019; 160(13): 502-508.
\end{abstract}

Kulcsszavak: myeloma multiplex, minimális residualis betegség, áramlásos citometria

\section{Impact of minimal residual disease detection after treatment of multiple myeloma}

Introduction: Prognostic impact of the detection of minimal residual disease (MRD) in multiple myeloma (MM) has been confirmed in numerous studies.

Aim: Retrospective examination of our patient database (107 newly diagnosed multiple myelomas between 2007 and 2017). Flow cytometry (FCM) was performed as MRD assessment.

Method: MRD assessment was performed in 56 patients (median age: 68 years), after induction treatment of multiple myeloma. The treatment contained bortezomib in 91\%, autologous haematopoetic stem cell transplantation (ASCT) was perfomed in $50 \%$. MRD detection was performed on bone marrow samples, predominantly in our hospital (BD FACScan, 3 colour, panel: CD38, CD138, CD19, CD45, CD56, CD28, CD117, cyKappa, cyLambda, 100000 events). Statistical analysis: SPSS 13.0. 
Results: The progression-free survival (PFS) and the overall survival (OS) were significantly longer in MRD negative $(\mathrm{n}=22)$ patients (PFS: 54 months, OS: 79\% after 5 years) than MRD positive patients ( $\mathrm{n}=34$, PFS: 22 months, OS $21 \%$ after 5 years, $\mathrm{p}=0.001)$. Patients achieving complete response $(C R)(\mathrm{n}=29)$ have different PFS (MRD negative CR: 60 months, MRD positive CR: 21 months, $\mathrm{p}<0.001)$. Patents achiving MRD negative very good partial response ( $\mathrm{n}=5$ ) have similar PFS ( 54 months) as patients with MRD negative CR. The longest PFS (68 months) was observed in MRD negative patients, after ASCT $(n=11)$, while the PFS was significantly $(\mathrm{p}<0.001)$ shorter in patients who were MRD positive after ASCT ( $\mathrm{n}=18$, PFS: 25 months), similarly in MRD positive patients without ASCT ( $\mathrm{n}=15$, PFS 21 months). Cox regression analysis (stage, cytogenetic risk, ASCT) confirmed that MRD is an independent prognostic factor of PFS and OS. We did not find significant relationship between MRD and stage, cytogenetic risk, number of treatment cycles, ASCT.

Conclusions: The depth of response after induction treatment of MM is an independent predictor of survival. MRD assessment with FCM is recommended to define response. Consideration of maintenance treatment in MRD positive patients and eradication of MRD are also recommended.

Keywords: multiple myeloma, minimal residual disease, flow cytometry

Szendrei T, Plander M, Szabó Zs, Kereskai L, Kajtár B, Papp G, Iványi JL. [Impact of minimal residual disease detection after treatment of multiple myeloma]. Orv Hetil. 2019; 160(13): 502-508.

(Beérkezett: 2018. november 7.; elfogadva: 2018. december 10.)

\section{Rövidítések}

ASCT $=$ (autologous stem cell transplantation) autológcsontvelö-transzplantáció; ASO-PCR = (allele specific oligonucleotide polymerase chain reaction) allélspecifikus oligonukleotid polimeráz-láncreakció; $\mathrm{CR}=$ (complete remission) komplett remisszió; $\mathrm{CT}=$ (computed tomography) számítógépes tomográfia; ELFO = elektroforézis; FCM = (flow cytometry) áramlásos citometria; FISH = fluoreszcens in situ hibridizáció; IMWG $=$ (International Myeloma Working Group) Nemzetközi Myeloma Munkacsoport; ISS = International Staging System; MM = (multiple myeloma) myeloma multiplex; MRD = (minimal residual disease $)$ minimális residualis betegség; MRI = (magnetic resonance imaging) mágnesesrezonanciaképalkotás; $\mathrm{NGF}=($ next generation flow $)$ új generációs áramlásos citometria; NGS = (next generation sequencing) új generációs szekvenálás; $\mathrm{OS}=($ overall survival $)$ teljes túlélés; $\mathrm{PAD}=$ bortezomib + doxorubicin + dexametazon; PET $=($ positronemission tomography) pozitronemissziós tomográfia; PFS = (progression-free survival) progressziómentes túlélés; PR = (partial remission) parciális remisszió; Thal $/$ Dex $=$ thalidomid + dexametazon; VCD = bortezomib + ciklofoszfamid + dexametazon; VD = bortezomib + dexametazon; VDT = bortezomib + dexametazon + thalidomid; VGPR $=($ very good partial remission) nagyon jó parciális remisszió; $\mathrm{VMP}=$ bortezomib + melfalan + prednizolon

A myeloma multiplex (MM) rosszindulatú hematológiai megbetegedés, amelyet monoklonális plazmasejtek csontvelói burjánzása jellemez. Jelen tudásunk szerint gyógyíthatatlan betegség, azonban az új antimyelomás szerek, az autológcsontveló-transzplantáció (ASCT) széles körû́ alkalmazása és a javuló szupportív kezelések mellett az utóbbi évtizedekben a várható medián túlélés (OS) jelentősen javult, 18 hónapról 72 hónapra. Indukciós kezelés után az International Myeloma Working Group (IMWG) kritériumai szerint (negatív szérum- elektroforézis és immunfixáció, 5\% alatti csontvelői plazmasejtarány) komplett remisszióba (CR) kerülő betegek aránya az új kezelések mellett $60 \%$-ra emelkedett [1-3]. A terápia célja már nem a betegség stabilizációja és rövid távú kontrollja, hanem a daganatos plazmasejtek minél mélyebb eradikálása a csontvelőboól, és így a hosszú túlélés és a későbbiekben talán a gyógyulás [2]. Az elmúlt másfél évtizedben került a figyelem középpontjába a MM kezelése után elért minimális maradék vagy minimális mérhető betegség (minimal residual disease, MRD) mérésének jelentősége; az ebben a témában megjelent publikációk száma exponenciálisan emelkedik (1.ábra).

Számos klinikai vizsgálat igazolta, hogy a mélyebb terápiás válasz, MRD-eradikáció a progressziómentes és teljes túlélést is szignifikánsan javította. Egy 2017-ben publikált metaanalízis [4] szerint, melyben 1273 beteg adatait dolgozták fel, az MRD-negatív betegek progreszsziómentes (PFS: 54 hónap) és teljes (OS: 98 hónap) túlélése is szignifikánsan jobb volt az MRD-pozitív betegek túlélési eredményeinél (PFS: 26 hónap, OS: 82 hónap).

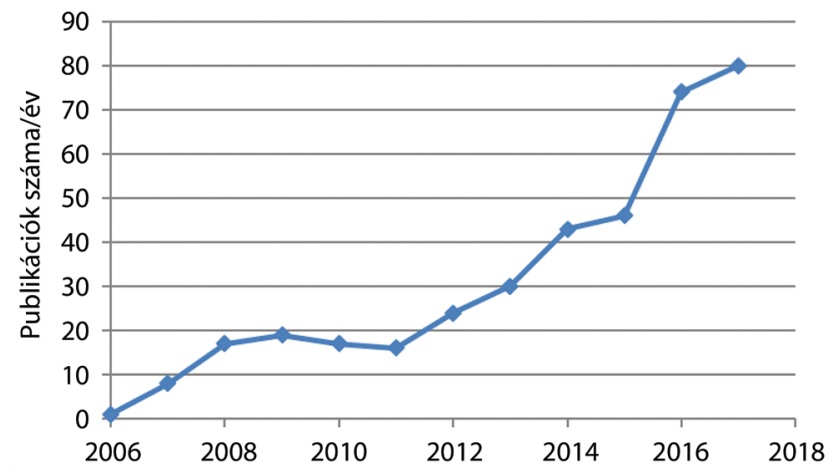

1. ábra $\quad$ A PubMed-adatbázisban megjelent publikációk száma a „multiple myeloma” és „minimal residual disease” keresőszavak alapján 
Az MRD folyamatos változó, különböző mélységekben vizsgálható paraméter. Egy tanulmány szerint a maradék myelomasejtek számában történt minden egyes log-redukció egy évvel megnyújtja a beteg várható túlélését [5]. A minimális residualis betegség mérésére jelenleg három módszer áll rendelkezésre myelomában: áramlásos citometria (FCM), allélspecifikus oligonukleotid polimeráz-láncreakció (ASO-PCR) és az új generációs szekvenálás (NGS). Ezen módszerek előnyeit, hátrányait foglalja össze az 1. táblázat [6].

1. táblázat |Az MRD-meghatározásra használt módszerek összehasonlítása

\begin{tabular}{llll}
\hline & FCM $(\geq 8$ szín $)$ & ASO-PCR & NGS \\
\hline Alkalmazható & $\sim 100 \%$ & $60-70 \%$ & $\sim 90 \%$ \\
$\begin{array}{l}\text { Hozzáférhetóség } \\
\text { Diagnosztikus } \\
\text { minta szükséges-e? }\end{array}$ & Néles körben kell & Közepes & Limitált \\
Időigény & $2-3$ óra & $>5$ nap & $>7$ nap \\
Ár & $\sim 350$ USD & $\sim 500$ USD & $\sim 700$ USD \\
Szenzitivitás & $10^{-5}$ & $10^{-5}-10^{-6}$ & $10^{-6}$ \\
Friss minta & Szükséges & Nem & Neltétlenül \\
& & szükséges & szükséges \\
\hline
\end{tabular}

Magyarországon jelenleg az áramlásos citometria érhető el széles körben erre a célra.

A klasszikus prognosztikai markerek és az MRD együttes értékelését jól szemlélteti Paiva és mtsai munkája [7], melyben a fluoreszcens in situ hibridizáció (FISH) és az MRD alapján három, prognosztikailag jól elkülönülő csoportba osztották az ASCT után CR-ba került betegeket. Jó prognózisú (MRD-negatív és FISH standard rizikójú) betegek PFS-e 83 hónap, a közepes prognózis (MRD-pozitív vagy FISH kedvezőtlen) esetén 26 hónap, nagy rizikó (MRD-pozitív és FISH kedvezötlen) esetén pedig 6 hónapnak bizonyult.

\section{Betegek és módszer}

A 2007. január 1. és 2016. december 31. között kórházunkban újonnan felismert myeloma multiplex miatt kezelt betegek adatainak retrospektív feldolgozása történt, az első vonalban alkalmazott kezelés után meghatározott MRD függvényében.

A fenti időszakban 107, újonnan diagnosztizált myeloma multiplex miatt kezdtünk kezelést.

Az éves medián incidencia 10,7, emelkedő tendenciával (2. ábra). Ezen 107 betegből 56 esetben történt az indukciós kezelés végén, csontvelői mintából áramlásos citometria és MRD-vizsgálat.

Az alábbiakban ezen 56 beteg adatait ismertetjük.

A betegek medián életkora 68 év volt, a férfi-női arány (48 : 52) enyhe női túlsúlyt mutatott. A betegek többsége (64\%) az International Staging System (ISS) szerint előrehaladott (3.) stádiumú volt, a 2 . stádiumban $23 \%$, az 1. stádiumban $13 \%$ került felismerésre. Plazmasejtes

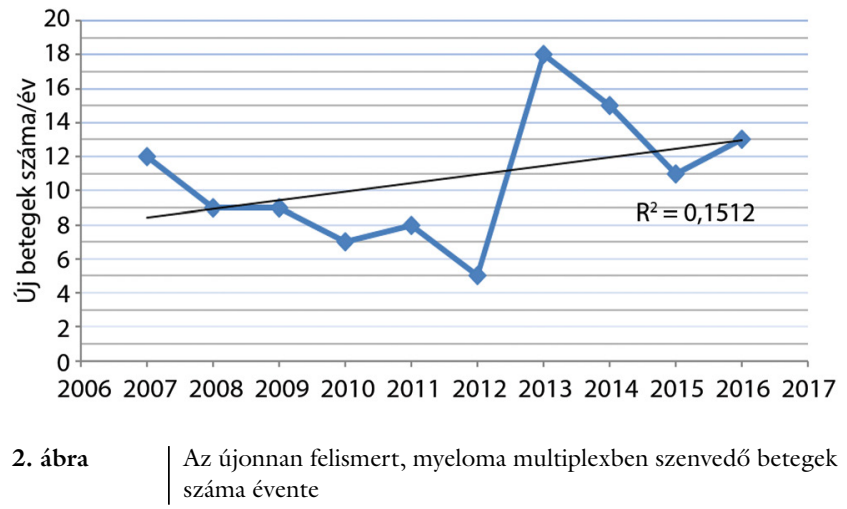

leukaemia 3\%-ban fordult elő. A diagnóziskor vett csontvelőben a plazmasejtek medián aránya $60 \%$-nak bizonyult.

Az 56 betegből 44 esetben történt a diagnóziskor vett csontvelői mintából interfázis-FISH a Semmelweis Egyetem I. Patológiai Intézetében; a vizsgálatok eredményeit foglalja össze a 3. ábra.

A betegek többsége (77\%) a FISH alapján standard rizikójú (negatív, hyperdiploid, t(11;14) transzlokáció);

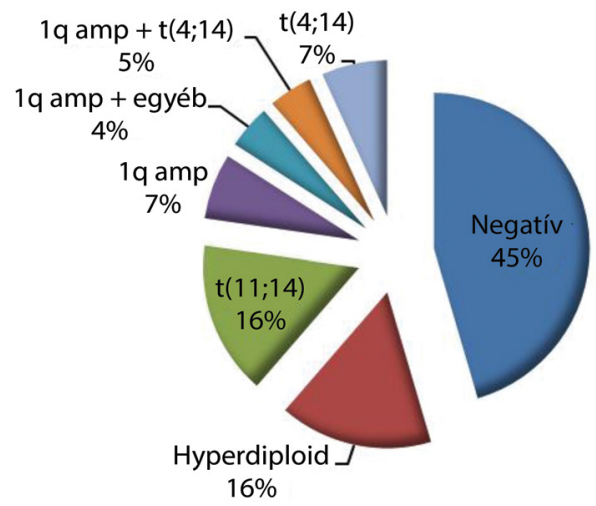

3. ábra | A FISH-eredmények megoszlása $(\mathrm{n}=44)$

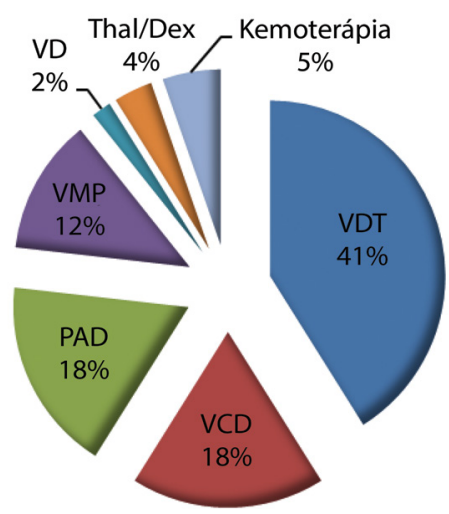

4. ábra $\quad$ A betegek megoszlása az indukciós kezelések szerint $(\mathrm{n}=56)$ $\mathrm{PAD}=$ bortezomib + doxorubicin + dexametazon; Thal $/ \mathrm{Dex}=$ thalidomid + dexametazon; VCD = bortezomib + ciklofoszfamid + dexametazon; VD = bortezomib + dexametazon; VDT = bortezomib + dexametazon + thalidomid; VMP = bortezomib + melfalan + prednizolon 
kedvezőtlen citogenetikai eltérés (1q amplifikáció, t $(4 ; 14)$ transzlokáció) $23 \%$-ban fordult elő.

A kezelés döntően (91\%) bortezomibbázisú indukciós kezelés (4. ábra).

Fiatal (70 év alatti) myelomás betegek indukciós kezelésének része az autológcsontvelő-transzplantáció is, amely a vizsgált betegek $50 \%$-ában történt meg.

A terápiás válasz felmérése során minden vizsgált betegnél szérumelektroforézis, immunfixáció mellett csontvelö-biopszia, hisztológia és immunhisztokémiai vizsgálat történt. A terápiás választ az IMWG- (2016) kritériumok szerint állapítottuk meg [6]: komplett remisszió (negatív immunfixáció, $<5 \%$ csontvelői plazmasejtarány), nagyon jó parciális remisszió (negatív ELFO mellett immunfixációval detektálható $\mathrm{M}$-protein vagy $M$-protein >90\%-os csökkenése), parciális remisszió (M-protein és/vagy csontvelői plazmasejtarány $>50 \%$-os csökkenése). A vizelet-ELFO és immunfixáció, a szérum-szabadkönnyưlánc arányának meghatározása a vizsgált időtartamban nem volt minden betegünknél elérhetô.

Az MRD vizsgálata döntően (84\%) kórházunkban történt, BD FACScan citométerrel, 3 színnel jelölve, 100000 eseményt analizálva. A betegek egy kisebb hányadában (a transzplantáción átesett, ASCT előtt még MRD-pozitív betegeknél) a transzplantáció utáni 100. napon Pécsett történt csontvelővizsgálat és áramlásos citometria eredményét (PTE Pathologiai Intézet) vettük figyelembe. Az alkalmazott módszerek összefoglalását mutatja a 2. táblázat.

A statisztikai számításokat SPSS 13.0 szoftverrel (SPSS Inc., Chicago, IL, Egyesült Államok) végeztük. KaplanMeier-féle túlélési görbéket készítettünk, a túlélésialcsoport-analíziseknél log-rank tesztet alkalmaztunk. Coxregressziót számoltunk a multivarianciaanalízis során, a

2. táblázat |MRD-meghatározásra alkalmazott módszerek

\begin{tabular}{|c|c|c|}
\hline A mérés helyszíne & Szombathely & $\begin{array}{l}\text { Pécs } \\
\text { (ASCT utáni } 100 . \\
\text { nap) }\end{array}$ \\
\hline A vizsgálatok száma & $\mathrm{n}=47$ & $\mathrm{n}=9$ \\
\hline $\begin{array}{l}\text { Az áramlásos } \\
\text { citométer gyártmá- } \\
\text { nya, a lézerek száma }\end{array}$ & $\begin{array}{l}2007.01 .-2016.12 .: \\
\text { BD FACScan } \\
3 \text { szin }\end{array}$ & $\begin{array}{l}\text { 2007. 01.-2008: } \\
\text { Partec, CyFlow } \\
\text { Space, } 5 \text { szin } \\
\text { 2008-2016. dec.: } \\
\text { Beckman Coulter } \\
\text { Navios, } 8 \text { szin }\end{array}$ \\
\hline Immunpanel & $\begin{array}{l}\text { CD38, } 138,19,45, \\
56,28,117, \\
\text { cykappa, cylambda } \\
(3 \text { csó) }\end{array}$ & $\begin{array}{l}\text { CD38, 138, 19, 45, } \\
56 \text { (Partec) } \\
\text { CD38, 138, 19, 45, } \\
56,117,20, \text { Syto } 41 \\
\text { (Beckman Coulter) }\end{array}$ \\
\hline $\begin{array}{l}\text { Az analizált } \\
\text { események száma }\end{array}$ & 100000 & $\sim 300000$ \\
\hline Szenzitivitás & $10^{-3}$ & $10^{-4}$ \\
\hline
\end{tabular}

kereszttáblák értékelésekor pedig Pearson-féle khi-négyzet-próbát alkalmaztunk. Az alcsoport-analízisek esetén az alacsony esetszám a statisztikai értékelést korlátozza.

\section{Eredmények}

A teljes beteganyagon $(\mathrm{n}=56)$ mért progressziómentes túlélés mediánja (PFS) 32 hónap, a teljes túlélés mediánja (OS) 53 hónap. Az 56 betegből 22 (39\%) beteg bizonyult MRD-negatívnak a kezelés végén. Ezen betegek progressziómentes (medián: 54 hónap) és teljes túlélése (a mediánt nem érték el) is szignifikánsan $(\mathrm{p}<0,01, \log$ rank) hosszabbnak bizonyult, mint a MRD-pozitív betegeknél mért PFS (medián: 22 hónap) és OS (medián: 44 hónap). Öt év után az MRD-negatív betegek 79\%-a, az MRD-pozitív betegek 21\%-a van életben (5. és 6. ábra).

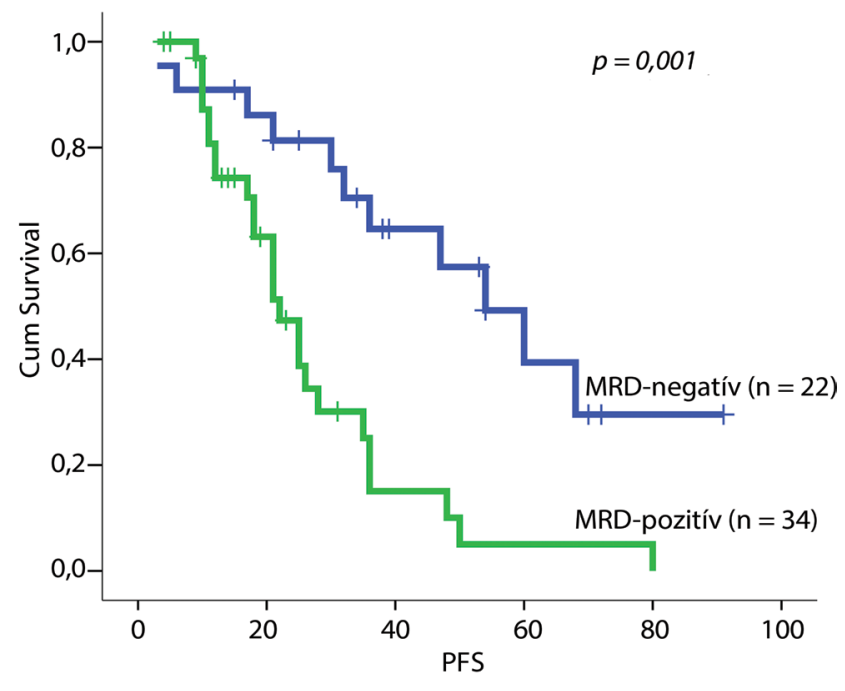

5. ábra | Progressziómentes túlélés (hónapok)

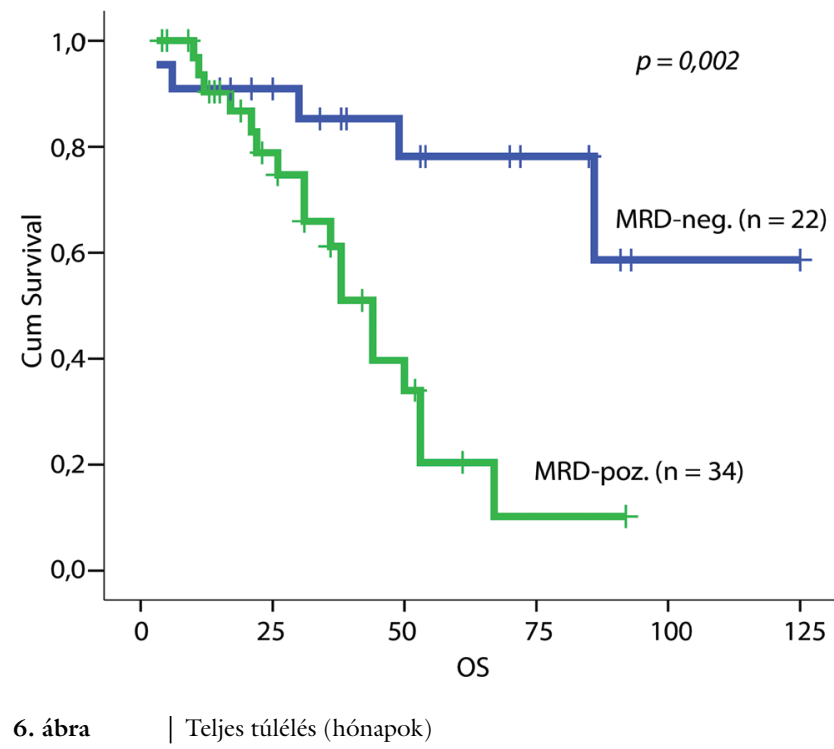


Az IMWG-kritériumok szerint komplett remisszióba került (ELFO, immunfixáció negatív, $<5 \%$ csontvelői plazmasejt) 29 beteg (52\%). Ezen betegek túlélése is jelentősen különbözött: MRD-negatív CR-ban szignifikánsan hosszabb PFS-t (medián: 60 hónap) és OS-t (a mediánt nem érték el) figyelhettünk meg, mint azoknál, akiknek a kezelés végén FCM-val még volt kimutatható kóros plazmasejt a csontvelőben (PFS medián: 21 hónap, OS medián: 38 hónap) (7. és 8 ábra).

Azon néhány betegnek ( $\mathrm{n}=5)$, akiknél a kezelés végén még volt kimutatható paraprotein, de MRD-negatívnak bizonyultak (MRD-neg. VGPR), a PFS-e (medián: 54 hónap) hasonló volt, mint MRD-neg. CR-ban ( $\mathrm{n}=17$, PFS medián: 60 hónap); az OS mediánt nem érték el. Az MRD-pozitív betegek túlélési görbéi az IMWG-státusztól (MRD-poz. CR: $\mathrm{n}=12, \mathrm{MRD}$-poz. PR: $n=22$ ) függetlenül egyaránt kedvezőtlenül alakul-

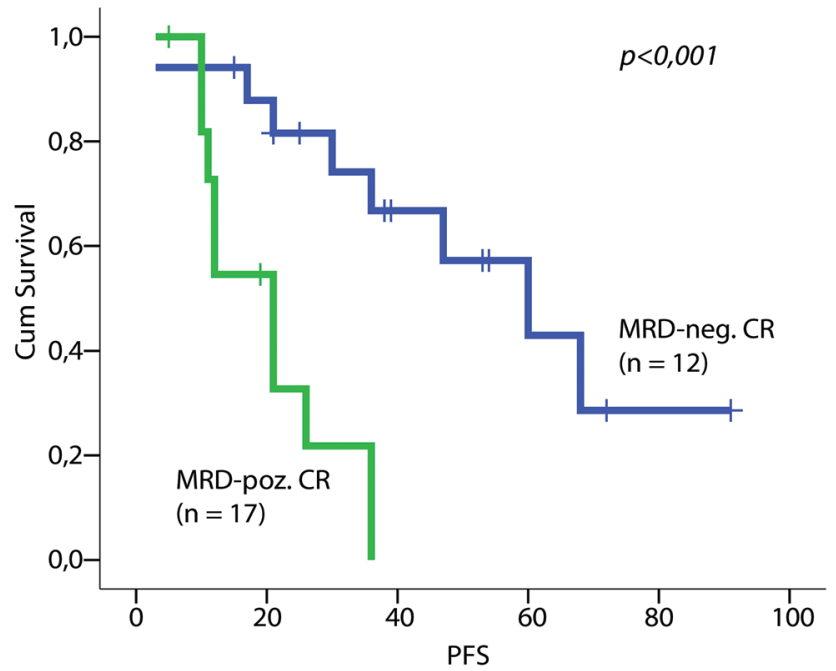

7. ábra | PFS CR-ban (hónapok)

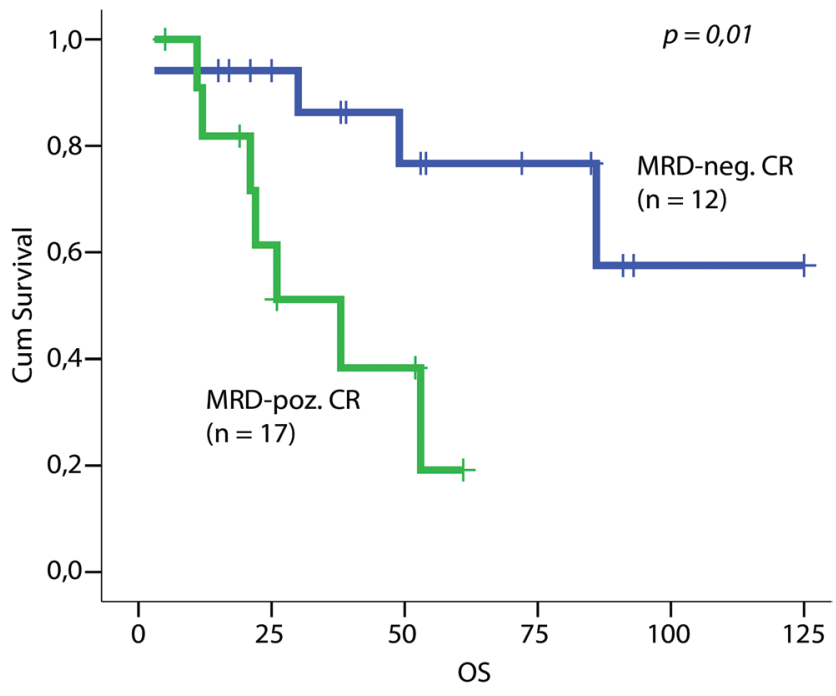

8. ábra $\quad$ OS CR-ban (hónapok) tak (PFS medián: 21, illetve 25 hónap, OS medián: 38, illetve 44 hónap) (9. és 10. ábra).

A leghosszabb progressziómentes túlélést a transzplantáción átesett, MRD-negatív $(\mathrm{n}=11)$ betegeknél mértük (PFS medián: 68 hónap, p<0,001), transzplantáció nélkül az MRD-negatív betegek $(\mathrm{n}=11)$ progressziója jóval korábban jelentkezett (PFS medián: 32 hónap). Az MRD-pozitív betegek (ASCT történt, MRD-poz.: $\mathrm{n}=18$, ASCT nem történt, MRD-poz.: $\mathrm{n}=16$ ) többsége két év után progressziót mutatott (PFS medián: 25, illetve 21 hónap). A betegek teljes túlélése az első remisszió időtartamával szoros összefüggést mutatott (11. és 12. ábra).

A bevezetőben említett modell [7] alapján megvizsgáltuk, hogy a citogenetikai (FISH-) rizikó és az MRD együttes értékelése beteganyagunkban mennyire volt prognosztikai szempontból reprodukálható. MRD-ne-

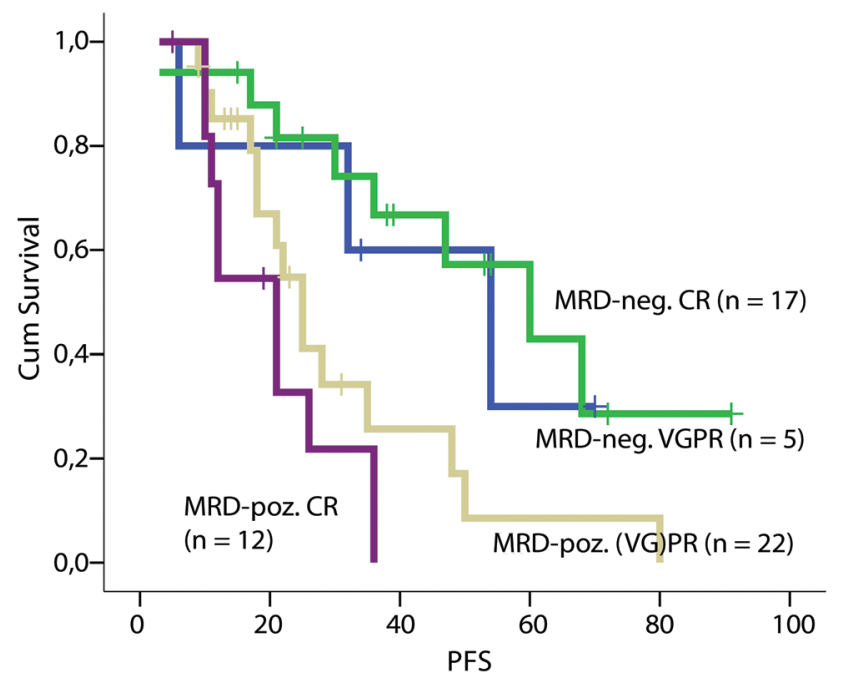

9. ábra

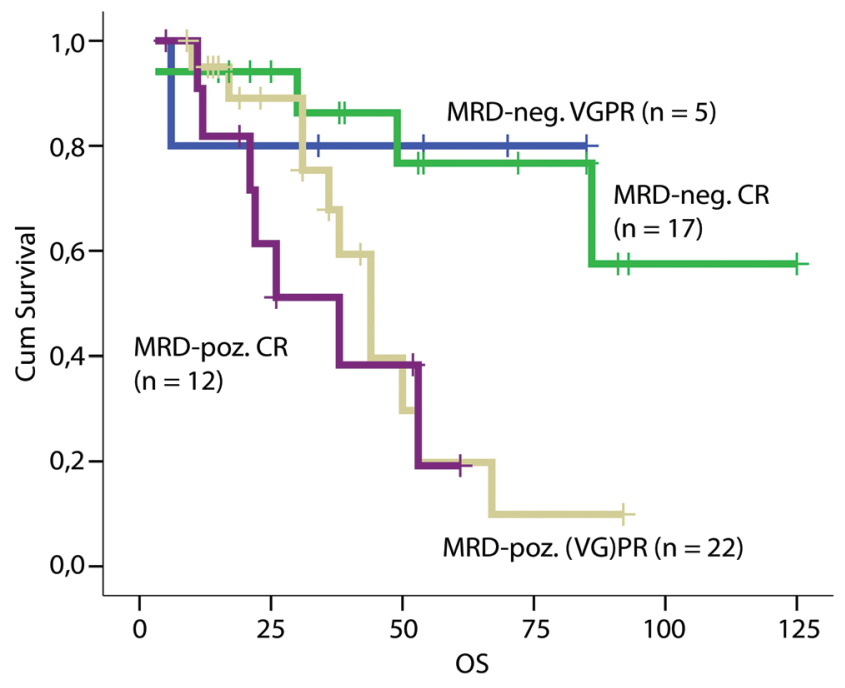

10. ábra $\mid$ MRD, IMWG szerinti OS (hónap) 


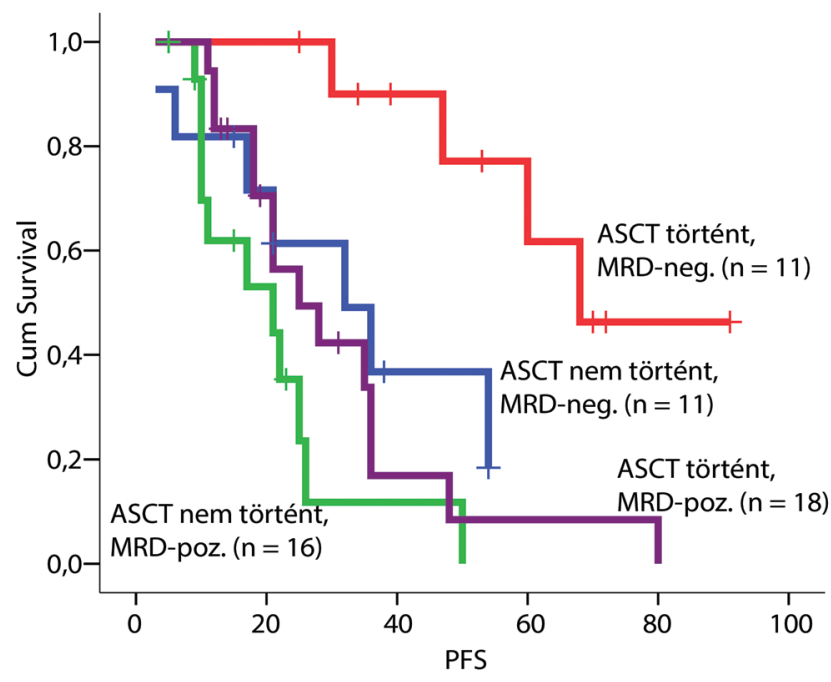

11. ábra $\mid$ MRD, ASCT szerinti PFS (hónap)

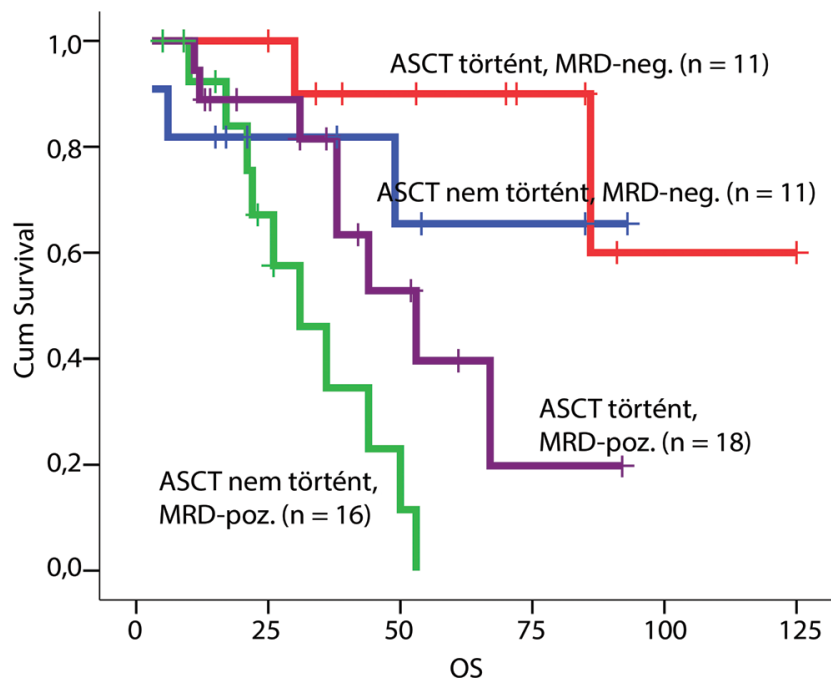

12. ábra $\quad$ MRD, ASCT szerinti OS (hónap)

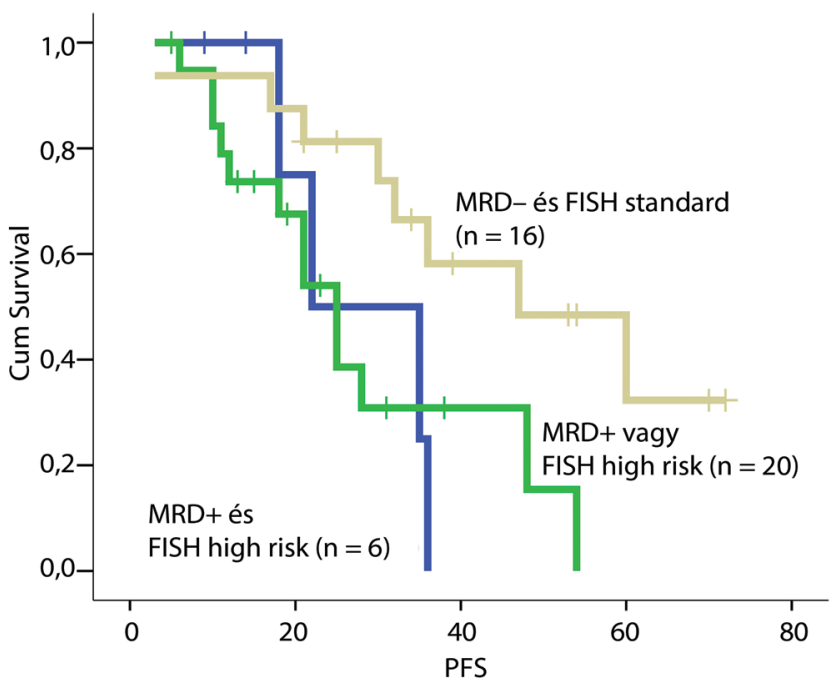

13. ábra $\mid$ MRD, FISH szerinti PFS (hónap) gatív és FISH alapján standard rizikójú betegek $(\mathrm{n}=16)$ esetén jelentősen hosszabb PFS-t mértünk (medián: 47 hónap), MRD-pozitív vagy kedvezőtlen FISH-betegcsoportban $(\mathrm{n}=20)$ a PFS rövidebb (medián: 25 hónap); MRD-pozitív és kedvezőtlen FISH $(n=6)$ mellett figyeltük meg a legrövidebb (medián: 22 hónap) PFS-t (13. ábra).

A kiindulási stádium (ISS-1, -2,-3), citogenetikai rizikó (FISH standard, kedvezőtlen) és transzplantáció (ASCT történt, nem történt) paraméterekkel multivarianciaanalízist (Cox-regresszió) végezve az MRD független prognosztikai faktornak bizonyult a PFS ( $\mathrm{p}=0,001$, hazard ratio $=4,85)$ és OS $(\mathrm{p}=0,042$, hazard ratio $=$ 3,966) vonatkozásában egyaránt.

Megvizsgáltuk, hogy a kiindulási betegség tömege (ISS-stádium), a citogenetikai rizikó (FISH), illetve az alkalmazott indukciós kezelés típusa, a ciklusok száma és a transzplantáció mennyire befolyásolta az MRD-eradikáció sikerességét. Beteganyagunkban nem találtunk szignifikáns összefüggést a fenti paraméterek és az MRDeredmények között (khi-négyzet-próba).

\section{Megbeszélés}

Beteganyagunk vizsgálata alapján - az irodalmi adatokkal egybehangzóan - megállapíthatjuk, hogy myeloma multiplexben az első remisszió időtartama és a túlélés szoros összefüggést mutat az indukciós kezelés után elért válasz mélységével.

A terápiás válasz pontos felméréséhez hozzátartozik a szérum-ELFO, az immunfixáció, a szabadkönnyúláncarány és a csontvelő szövettani vizsgálatain kívül az MRD meghatározása, mely hazánkban is elterjedóben van, és további fejlesztést, standardizációt igényel [8].

Nemzetközi ajánlások [6,9-11] szerint MRD-negatív a minta, ha az új generációs áramlásos citometriával, az EuroFlow irányelvei szerint végezve a vizsgálatot $10^{5}$ csontvelői magvas sejtből nem mutatható ki kóros fenotípusú plazmasejt. A vizsgálat standardizálása és a szenzitivitás fokozása érdekében a Flores-Montero és mtsai által kidolgozott módszer [12] szerint végzett új generációs áramlásos citometria (NGF) érzékenysége $\left(10^{-6}\right)$ megközelíti az új generációs szekvenálás érzékenységét. A meghatározott antitestpanellel (2 csőben, 8 színnel, 12 marker), úgynevezett bulk-lysis után $10^{7}$ csontvelői sejtet analizálva érhető el a fenti szenzitivitás. A dolgozatban bemutatott módszer elmarad a jelenlegi követelményektól (szenzitivitás $10^{-3}$ ), kórházunkban azonban ez több mint egy évtizede a rutin klinikai munka során végzett vizsgálat, melynek korlátait ismerve is megállapítható, hogy alkalmas a maradék betegség kimutatására és a várható prognózis becslésére. 2017-től a módszer szenzitivitása tovább javult kórházunkban is az új citométer (FACSCanto II, 8 szín) használatával, így a továbbiakban már a jelenlegi ajánlások szerint vizsgálhatjuk az MRD-t. 
Az indukciós kezelés végén mért MRD a progressziómentes és teljes túlélés független és legfontosabb prediktora. A közeljövőben az MRD-negatív állapot elérése lehet majd az egyik legfontosabb terápiás cél, mert a hosszabb túlélés mellett az első remisszió időtartama (kezelési szünet) a betegek életminőségét is alapvetően meghatározza.

A gócos csontvelői infiltráció miatt előfordulhat, hogy a csontvelői mintavétel nem reprezentatív, ezért a terápiás válasz felmérése során a negatív MRD-eredményt érdemes konfirmálni PET/CT-vel vagy a kórházunkban szintén évek óta elérhető diffúziósúlyozott MRI-vel [13] vagy a két vizsgálat előnyeit egyesítő PET/MRI-vel [14].

Az irodalmi adatokkal [15] megegyezően azt találtuk, hogy paraprotein kimutatható lehet MRD-negatív betegeknél is, akiknél a kimenetel hasonlóan kedvező, mint akik MRD-negatív komplett remisszióba kerültek. Ennek oka lehet az elhúzódó paraproteinclearance.

Az MRD-negatív betegek közül a transzplantáció után észlelt, jelentősen hosszabb remisszió valószínúleg az alkalmazott módszer detektálási határa $\left(10^{-3}\right)$ alatt elért mélyebb válasz eredménye.

A prognózis megítélésekor a klasszikus prognosztikai markereket (például FISH) és a kezelés végén meghatározott MRD-t együttesen kell értékelni.

Indukciós kezelés végén kimutatható MRD esetén a korai relapsus veszélye miatt megfontolandó a konszolidáló és/vagy fenntartó kezelés, komplett remisszió esetén is.

Anyagi támogatás: A közlemény megírása anyagi támogatásban nem részesült.

Szerzői munkamegosztás: Sz. T.: Adatgyưjtés, feldolgozás, statisztikai számítások elvégzése, a közlemény megírása. P. M.: Áramlásos citometriai mérések, adatszolgáltatás, szakmai tanácsadás. Sz. Zs.: Adatgyưjtés. K. L., K. B.: Áramlásos citometriai mérések. P. G.: FISH-vizsgálatok. I. J. L.: Adatszolgáltatás, szakmai tanácsadás. A közlemény végleges változatát valamennyi szerző elolvasta és jóváhagyta.

Érdekeltségek: A szerzőknek nincsenek érdekeltségeik.

\section{Irodalom}

[1] Davies FE. Is molecular remission the goal of multiple myeloma therapy? Hematology Am Soc Hematol Educ Program 2017; 2017: 205-211.
[2] Barlogie B, Mitchell A, van Rhee F, et al. Curing myeloma at last: defining criteria and providing the evidence. Blood 2014; 124 : 3043-3051.

[3] Kumar S, Paiva B, Anderson KC, et al. International Myeloma Working Group consensus criteria for response and minimal residual disease assessment in multiple myeloma. Lancet Oncol. 2016; 17: 328-346.

[4] Munshi N, Avet-Loiseau H, Rawstron A, et al. Association of minimal residual disease with superior survival outcomes in patients with multiple myeloma - a meta-analysis. JAMA Oncol. 2017; 3: 28-35.

[5] Rawstron A, Gregory WM, Tute RM et al. Minimal residual disease in myeloma by flow cytometry: independent prediction of survival benefit per log reduction. Blood 2015; 125: 1932-1935.

[6] Paiva B, van Dongen JM, Orfao A. New criteria for response assessment: role of minimal residual disease in multiple myeloma. Blood 2015; 125: 3059-3068

[7] Paiva B, Gutiérrez NC, Rosiñol L, et al. High-risk cytogenetics and persistent minimal residual disease by multiparameter flow cytometry predict unsustained complete response after autologous stem cell transplantation in multiple myeloma. Blood 2012; 119: 687-691.

[8] Varga G, Mikala G, Váróczy L, et al. Management of multiple myeloma in Hungary in 2016. [A myeloma multiplex megközelítése Magyarországon 2016-ban.] Orv Hetil. 2016; 157: 123-137. [Hungarian]

[9] Stetler-Stevenson M, Paiva B, Stoolman L, et al. Consensus guidelines for myeloma minimal residual disease sample staining and data acquisition. Cytometry B Clin Cytom. 2016; 90: 2630 .

[10] Flores-Montero J, de Tute R, Paiva B, et al. Immunophenotype of normal vs. myeloma plasma cells: toward antibody panel specifications for MRD detection in multiple myeloma. Cytometry B Clin Cytom. 2016; 90: 61-72.

[11] Arroz M, Came N, Lin P, et al. Consensus guidelines on plasma cell myeloma minimal residual disease analysis and reporting. $\mathrm{Cy}-$ tometry B Clin Cytom. 2016; 90: 31-39.

[12] Flores-Montero J, Sanoja-Flores L, Pavia B, et al. Next Generation Flow for highly sensitive and standardized detection of minimal reisdual disease in multiple myeloma. Leukemia 2017; 31 : 2094-2103.

[13] Caers J, Withofs N, Hillengass J, et al. The role of positron emission tomography-computed tomography and magnetic resonance imaging in diagnosis and follow up of multiple myeloma. Haematologica 2014; 99: 629-637.

[14] Tóth Z, Lukács G, Cselik Zs, et al. Hungarian clinical application opportunities of PET/MR imaging and first experiences. [A PET/MR képalkotás magyarországi klinikai alkalmazásának lehetőségei, első tapasztalatai.] Orv Hetil. 2018; 159: 13751384. [Hungarian]

[15] Paiva B, Martinez-Lopez J, Vidriales MB, et al. Comparison of immunofixation, serum free light chain, and immunophenotyping for response evaluation and prognostication in multiple myeloma. J Clin Oncol. 2011; 29: 1627-1633.

(Szendrei Tamás dr., Szombathely, Markusovszky Lajos u. 5., 9700 e-mail: dr.szendrei.tamas@gmail.com)

A cikk a Creative Commons Attribution 4.0 International License (https://creativecommons.org/licenses/by/4.0/) feltételei szerint publikált Open Access közlemény, melynek szellemében a cikk bármilyen médiumban szabadon felhasználható, megosztható és újraközölhetö, feltéve, hogy az eredeti szerző és a közlés helye, illetve a CC License linkje és az esetlegesen végrehajtott módositások feltüntetésre kerülnek. (SID_1) 